\title{
Placental Transfer of Haemophilus influenzae Type b Antibodies in Malnourished Pregnant Women
}

\author{
Rejane S. Cavalcante ${ }^{1}$, Benjamin I. Kopelman ${ }^{2}$ and Beatriz T. Costa-Carvalho ${ }^{2}$ \\ ${ }^{1}$ Department of Integrated Health, University State of Pará; Belém, PA; ${ }^{2}$ Department of Pediatrics, Federal University of São Paulo - Medical \\ School of São Paulo (UNIFESP-EPM); São Paulo, SP, Brazil
}

\begin{abstract}
This study evaluated the vaccination response to Haemophilus influenzae type b (Hib) in malnourished pregnant women (MN), cord blood (CB) and in infants at two and six months of age for comparison with a control group (C). Twenty-eight malnourished pregnant women and 29 pregnant controls were immunized with conjugated Act-HIBß in the third trimester of pregnancy. Blood samples were collected from all before the immunization, during labor (post immunization), and from CB. All infants were immunized with Hib vaccine according to normal vaccine schedule and sera were collected at two and six months of age. Antibody levels to polyribosylribitol phosphate (PRP) were similar for both groups. Preimmunization: MN $1.94 \mu \mathrm{g} / \mathrm{mL}, \mathrm{C} 1.68 \mu \mathrm{g} / \mathrm{mL}$; post-vaccination: $\mathrm{MN} 18.53 \mu \mathrm{g} / \mathrm{mL}$ and $\mathrm{C} 17.55 \mu \mathrm{g} / \mathrm{mL}$; in $\mathrm{CB}$ from $\mathrm{MN} 14.46 \mu \mathrm{g} / \mathrm{mL}$ and from $\mathrm{C} 17.04 \mu \mathrm{g} / \mathrm{mL}$. Infants from $\mathrm{MN}$ and $\mathrm{C}$ mothers presented respectively at two months: $5.18 \mu \mathrm{g} / \mathrm{mL}$ and $8.60 \mu \mathrm{g} / \mathrm{mL}$ and at six months: $\mathrm{MN} \mathrm{3.42} \mu \mathrm{g} / \mathrm{mL}$ and C $2.18 \mu \mathrm{g} / \mathrm{mL}$. Antibody levels were similar in both groups studied $(p=\mathbf{0 . 4 8 5})$, however the vertical transmission rate was $14 \%$ lower in the MN pregnant group. Levels of antibodies $\geq 0.15 \mu \mathrm{g} / \mathrm{mL}$ were found in all newborns from the MN pregnant group. Pregnant MN presented an immunological response to Hib vaccine similar to group $\mathrm{C}$, however, vertical transmission rate of antibodies to PRP in the MN pregnant group was $14 \%$ lower than that in $\mathrm{C}$, suggesting a less efficient passage of antibodies within this group.

Key-Words: Pregnant women, malnourished, Haemophilus influenzae type b, passive immunization, vaccine, antibodies, immunoglobulin G.
\end{abstract}

The fetus passive immunization from the pregnant woman's vaccination was recognized in 1879 when Bukhardt demonstrated the protection of children whose mothers had been vaccinated against smallpox [1]. Some vaccines commercially available are considered safe when administered during pregnancy [2], and provide an increase in antibody levels for the following pathogens: diphtheria, tetanus toxoids, mumps, meningococcus and Hib [2-9].

Based on these results, active maternal immunization has been proposed against other microorganisms which can cause infection in early life such as group B streptococcus (GBS), respiratory syncytial virus, pneumococcus, hepatitis $B$ and influenza [10-13].

Some studies have shown that capsular polysaccharide vaccine PRP administered to the pregnant woman results in a significant increase in antibody concentration to PRP in the newborn [14] and in the four weeks old breastfed infant [9], protecting them for up to six months or more, without affecting their response capacity to active immunization at two, four, six and 24 months of age $[6,8,9,15]$.

Adequate nutrition is essential for immunocompetence, and nutritional deficiency is a frequent cause of secondary immunodeficiency globally [16]. There is evidence that a relevant percentage of Brazilian women are at risk or suffer from protein-energy malnutrition $[17,18]$. Furlan at al. reported a prevalence of malnutrition during pregnancy of $27.7 \%$ [19] Received on 10 September 2007; revised 28 January 2008.

Address for correspondence: Dr. Rejane Silva Cavalcante. Travessa Quintino Bocaiúva, 981. Apt. 2100. Reduto. Belém. Pará. Zip code: 66053240. Phones: (91) 32253772 - home; 40089535 - office; fax 40089500. crejane@ig.com.br. Research grant from: UNIFESP.

The Brazilian Journal of Infectious Diseases

2008;12(1):47-51. (C) 2008 by The Brazilian Journal of Infectious Diseases and Contexto Publishing. All rights reserved. and Rosado observed that $39.1 \%$ of pregnant teenagers started pregnancy undernourished [20].

Maternal malnutrition may affect placental size decreasing its functions by providing a smaller amount of nutrients to the fetal organs [21], jeopardizing fetal growth and contributing to a greater perinatal morbidity and mortality $[22,23]$.

The transplacental IgG transport involves a connection to the Fc receptor on the surface of syncytiotrophoblast [24], however, some clinical conditions such as maternal HIV infection, malaria, prematurity and maternal hypergammaglobulinemia may interfere with this transport, but we did not observe reports of changes in the placental passage of antibodies in malnourished pregnant women [25-29].

The objective of our study was to assess response to Haemophilus influenzae type b (Hib) vaccine in malnourished pregnant women $(\mathrm{MN})$, and levels of these antibodies in cord blood (CB) and in infants at two and six months, comparing them to a control group (C).

\section{Material and methods}

This study was approved by the Ethical Committee on Research of UNIFESP and was developed at Santa Casa de Misericórdia do Pará, a reference center in the state of Pará for high risk pregnancies.

Twenty-eight (28) malnourished pregnant women (MN), and 29 from a control pregnant group (C) were selected at 3034 weeks gestation after signed a term of consent. Women with high risk pregnancies as chronic diseases were excluded, also newborns with congenital anomalies.

The interviews and anthropometric assessments were carried out by the same person under appropriate conditions. To determine the nutritional state, Rosso normogram was used, as recommended by the World Health Organization (WHO) 
and proposed by the Ministry of Health. The monogram considers malnourished those pregnant women whose weight and height relations are below $95 \%$ in early pregnancy and $123 \%$ below the ideal weight at the final stage, using the curve of weight gain during pregnancy [30].

A single intramuscular dose of Act-HIB $®$ vaccine (lot 3206), Pasteur Mérieux, $0.5 \mathrm{~mL}$ (10 mcg PRP), was administered in the deltoid region to all the women between 30 and 34 weeks of gestation. Adverse reactions were monitored during the first 24 hours and a week after immunization. All infants were immunized against Hib at two, four and six months of age.

Preimmunization (immediately before vaccination) and post-immunization (up to 24 hours after delivery) blood samples, with a minimum interval of three weeks between pre and post-immunization samples, were collected from 57 pregnant women (28 MN and 29 C). Cord blood (CB) samples were collected from all of them. These infants were evaluated and peripheral blood samples were collected at two ( 17 from MN mothers and 20 from C) and six months of age (16 from $\mathrm{MN}$ mothers and $18 \mathrm{C}$ ), before the first and the third Hib vaccine doses respectively.

The blood samples were kept at $-20^{\circ} \mathrm{C}$ and the dosage of specific antibodies of IgG class to PRP was done using ELISA (BINDAZYME $^{\mathrm{TM}}$ Anti-Haemophilus B - MK016) test. The results were analyzed using the descriptive data analyses and the following statistical tests: chi-square, repeated measures analysis of variance, Pearson's correlation, Student's t-test, all conducted through the BioEstart 3.0 software. It was considered significant when $\mathrm{p} \leq 0.05$. Levels of antibodies $\geq$ $0.15 \mu \mathrm{g} / \mathrm{mL}$ were considered protectors against infection by Hib and $\geq 1.0 \mu \mathrm{g} / \mathrm{mL}$ for long term protection [31].

\section{Results}

There was a significant difference in the pregnant women's weight/height mean between the two groups when they were immunized. However, the weight of newborns did not show any difference between the two groups (Table 1).

The comparison of PRP antibody levels pre and postimmunization between the two gestational groups ( $\mathrm{MN}$ and $\mathrm{C})$, using repeated measured analysis of variance, did not detect any difference between them $(\mathrm{p}=0.485)$ (Table 2).

Approximately $60 \%$ of the pregnant women presented antibody levels $\geq 1.00 \mu \mathrm{g} / \mathrm{mL}$ before immunization and these levels were reached for all after immunization. Even after regular immunization in infants, not everyone presented levels $\geq 1.00$ $\mu \mathrm{g} / \mathrm{mL}$ at six months old (Table 3 ) and three from the control group had levels lower than $0.15 \mu \mathrm{g} / \mathrm{mL}$.

We observed a moderate to strong association between the antibody concentration to PRP of post-immunized pregnant women and of the $\mathrm{CB}$ of group $\mathrm{C}$ (Pearson linear correlation $=0.583$ ).

Applying " $\mathrm{t}$ " Student test for independent samples, we observed that the ratio of placental antibody transfer to PRP was $14 \%$ lower in the malnourished pregnant women group (Table 4).

\section{Discussion}

Adequate nutrition is required for a good functioning of the immunological system. Apart from the macronutrients deficiency, subclinical deficiencies of micronutrients affect morbid-mortality related to infection, which make them possibly responsible for changes in humoral and cellular immunity $[32,34]$. The difference in weight in the two groups, lower in the malnourished one, despite being taller, reinforces the classification as malnourished in this group. However, this difference did not interfere with the baby weight at birth, the most common interpretation of malnourishment during pregnancy $[30,35]$.

Studies with different types of Hib vaccine have been used in pregnant women, as a safe and efficient way to provide antibodies [36]. Administration is recommended after the $30^{\text {th }}$ week of gestation [9], as little maternal antibodies are transferred to the fetus before this period.

Although the pregnant women in both groups lived in unfavorable environments from the point of view of hygiene, we detected very low levels of pre-immunization antibodies to Hib. Approx $40 \%$ of pregnants $\mathrm{MN}$ and $\mathrm{C}$ presented $\mathrm{IgG}$ levels to PRP lower than $1 \mu \mathrm{g} / \mathrm{mL}$, similar to those found in a group of well-nourished non immunized Brazilian women [29]. The interval between mothers' immunization and the babies deliveries was at least three weeks, sufficient for the antibody secretion and transplacental transfer [7]. Only three pregnant women from group $\mathrm{MN}$ and one from group $\mathrm{C}$ did not present an increase in the levels of antibodies to PRP postimmunization, however they already showed high levels at the time of immunization. There was an average of a ten fold increase in the mean of antibody concentration in the postimmunization in relation to the pre-immunization, including the pregnant group $\mathrm{MN}$, who demonstrated a capacity for response to Hib antigens. Conjugated vaccines administered to pregnant women showed an important elevation in the antibody levels to PRP that could be a hundred times higher than the pre-vaccination values [37] probably due to the predominant induction of $\operatorname{IgG} 1$ antibody production, conferring a high elevation of these antibodies to newborns whose mothers were immunized [29,36].

In this study, pregnant group $\mathrm{MN}$ presented a transplacental transfer of antibodies $14 \%$ lower than the control group. Michaux et al. were the first to report that the pattern of placental antibody transfer of IgG may decrease when the level of this antibody reaches high values and that the higher maternal concentration of IgG to PRP is associated with a less efficient transplacental transfer [38], however, we couldn't confirm this observation. There is no evidence in the literature of data concerning the tansplacental transfer of antibodies in malnourished pregnant women. One must consider that the transport of antibodies across the placenta to the fetus is an active process which requires an intact and healthy placenta. The inherent factors from the mother are the ones that contribute most to the nutritive placental insufficiency, whether through reduction of nutrients, or 
Table 1. Means of anthropometric characteristics and gestational ages of pregnant and newborns

\begin{tabular}{lccc}
\hline & $\begin{array}{c}\text { Malnourished } \\
\text { pregnant }(\mathbf{M N})\end{array}$ & $\begin{array}{c}\text { Pregnant } \\
\text { control }(\mathbf{C})\end{array}$ & $\begin{array}{c}\text { Value of p of Chi- } \\
\text { square test }\end{array}$ \\
\hline Pregnants' average weight at time of vaccination & $56.89 \mathrm{Kg}$ & $65.05 \mathrm{Kg}$ & $\mathrm{p}=0.010^{*}$ \\
Pregnants' average height at time of vaccination & $1.56 \mathrm{~m}$ & $1.53 \mathrm{~m}$ & $\mathrm{p}=0.038^{*}$ \\
Average gestational ages of newborns & 39.13 weeks & 39.32 weeks & $\mathrm{p}=0.683$ \\
Newborns' average weight & $3.163 \mathrm{~g}$ & $3.224 \mathrm{~g}$ & $\mathrm{p}=0.621$ \\
\hline
\end{tabular}

$* \mathrm{p}<0.05$.

Table 2. Serum levels of $\operatorname{IgG}(\mu \mathrm{g} / \mathrm{mL})$ to polyribosylribitol phosphate (PRP) in malnourished pregnant women (MN) and controls (C) pre and post immunization, cord blood (CB) and in children at 2 and 6 months of age

\begin{tabular}{|c|c|c|c|c|c|}
\hline \multirow{2}{*}{ Group } & \multicolumn{2}{|c|}{ Pregnant } & \multirow{2}{*}{ CB } & \multirow{2}{*}{2 months } & \multirow{2}{*}{6 months } \\
\hline & Pre- & Post- & & & \\
\hline \multicolumn{6}{|l|}{$\mathrm{MN}$} \\
\hline Geometric mean & 1.94 & 18.53 & 14.46 & 5.18 & 3.42 \\
\hline Minimum & 0.30 & 8.70 & 5.60 & 0.30 & 0.30 \\
\hline Maximum & 24.60 & 24.00 & 24.00 & 22.00 & 24.00 \\
\hline $\mathrm{N}$ & 28 & 28 & 28 & 17 & 18 \\
\hline \multicolumn{6}{|l|}{$\mathrm{C}$} \\
\hline Geometric mean & 1.68 & 17.55 & 17.04 & 8.60 & 2.18 \\
\hline Minimum & 0.10 & 3.00 & 4.00 & 0.50 & 0.10 \\
\hline Maximum & 21.60 & 24.40 & 23.00 & 22.00 & 24.00 \\
\hline $\mathrm{N}$ & 29 & 29 & 29 & 20 & 16 \\
\hline
\end{tabular}

Table 3. Percentage (\%) of pregnant women, newborns and infants at 2 and 6 months of age with concentration of $\mathrm{IgG}(\mu \mathrm{g} / \mathrm{mL})$ to polyribosylribitol phosphate $(\mathrm{PRP})>0.15 \mu \mathrm{g} / \mathrm{mL}$ and $>1.0 \mu \mathrm{g} / \mathrm{mL}$, according to nutrition status in pregnant woman

\begin{tabular}{lccc}
\hline & Antibody concentration to PRP $\boldsymbol{\mu g} / \mathbf{m L}$ & Malnourished $(\boldsymbol{\%})$ & Control $(\%)$ \\
\hline Pre-immunization & $\geq 0.15$ & 100 & 96.5 \\
& $\geq 1.00$ & 57.4 & 65.5 \\
Post- immunization & $\geq 0.15$ & 100 & 100 \\
& $\geq 1.00$ & 100 & 100 \\
Cord blood & $\geq 0.15$ & 100 & 100 \\
& $\geq 1.00$ & 100 & 100 \\
2 months & $\geq 0.15$ & 100 & 100 \\
& $\geq 1.00$ & 94.7 & 95.8 \\
6 months & $\geq 0.15$ & 100 & 83.3 \\
& $\geq 1.00$ & 75.0 & 66.6 \\
\hline
\end{tabular}

Table 4. Ratio of concentration of antibody placental transfer between cord blood and mother in each group

\begin{tabular}{lccc}
\hline Group & Malnourished pregnant (MN) & Control pregnant (C) & Total \\
\hline Mean & $0.84^{*}$ & $0.98^{*}$ & 0.91 \\
Standard - deviation & 0.29 & 0.24 & 0.27 \\
Minimum & 0.29 & 0.24 & 0.24 \\
Maximum & 1.44 & 1.35 & 1.44 \\
\hline
\end{tabular}

*Difference of transference ratio between the two groups: $14 \%$. 
through reduction of the flux of placenta [39]. The relation between protein energy malnutrition and the baby weight at birth has been assessed since the 50's [1,17]. Smaller contents of DNA, RNA and proteins have been shown in rats born from malnourished females by restriction of weight [40].

Infants of two months of age before the first immunization against Hib, from both groups ( $\mathrm{MN}$ and $\mathrm{C}$ ), presented the same antibodies levels and almost all (95\%) infants had levels of antibodies above $1 \mu \mathrm{g} / \mathrm{mL}$. Similar results were observed in the USA using conjugated vaccine - PRP-D in breastfed children of vaccinated mothers with PRP-T in Gâmbia [8,9]. Both of our pregnant groups studied were of a low socioeconomic level, apparently more similar to the Gambian population than that of the USA. Maternal malnutrition in our pregnant women doesn't seem to be a limiting factor in vaccination response and in the maintenance of concentration of these antibodies in their children at 2 months of age and at 6 months after a regular vaccine schedule. There was no child in pregnant group $\mathrm{MN}$ with an unprotective level of $\mathrm{Hib}$ antibody.

At 6 months of age, before the third dose of vaccination, no difference was observed in the concentration of antibodies between groups $\mathrm{MN}$ and $\mathrm{C}$ and, more than 50\% of them presented levels of protective Hib antibodies. Similar results were found by Englund JA [9]. Mulholland K. et al, observed that a greater number of children born from immunized mothers presented protective levels of antibodies to PRP, without interference with the active immunization, when compared to children born from nonimmunized mothers during pregnancy [8]. This point must be considered because it deals with a population that has been exposed to high risks of infection by Hib, especially in developing countries, when associated with the problem of malnutrition.

From birth to 6 months of age there was a decrease in the levels of antibodies to PRP in both groups; a consequence of the half-life of maternal antibodies and the lack of time for the complete immunological response to the vaccine.

This study demonstrates an adequate immunological response to vaccine against Hib in malnourished pregnant women. Although the antibody concentration, was similar in the two groups, the antibody transplacental transfer to PRP was $14 \%$ lower in the malnourished group. This draws attention to the lower antibody transplacental transfer against Hib in this group who are considered at a higher risk to have low birth weight babies.

\section{Acknowledgments}

We thank Dr. Paulo Azevedo for assistance in the research.

\section{References}

1. Bukhardt A.E. Zur intrauterine vaccination. Deustsches Arch Clin Med (1879) apud Linder N, Ohel G. In utero vaccination. Clin in Perinatol 1994; $1: 663$.

2. Amstey M.S. The potential for maternal immunization to protect against neonatal infections. Semin Perinatol 1991;15:206-209.
3. Dengrove J., Lee E.J., Heiner D.C., et al. IgG and IgG subclassspecific antibody responses to diphtheria and tetanus toxoids in newborns infants given DPT immunization. Pediatr Res 1986;20:735-9.

4. Sato H., Albrecht P., Reynolds D.W., et al. Transfer of measles, mumps, rubella antibodies from mother to infant. Its effect on measles, mumps, and rubella immunization. Am J Dis Child 1979; $133: 1240-3$.

5. McCormick J., Gusmao H., Nakamura S., et al. Antibody response to serogroup $\mathrm{A}$ and $\mathrm{C}$ meningogoccal polyssacaride vaccines in infants born of mothers vaccinated during pregnancy. J Clin Invest 1980;65(5):1141-4.

6. Letson W.G., Santosham M., Raymond R., et al. Comparision of ative and combined passive/active immunization of Navarro children against Haemophilus influenzae type b. Pediatr Infect Dis J 1988;7:747-52.

7. Glesen P.W., Englund J.Á., Siber G.R., et al. Maternal Immunization with capsular polysaccharide vaccine for Haemophilus influenzae type b. J Infect Dis 1992;165:S134-6.

8. Mulholland K., Suara R.O., Siber G., et al. Maternal imunization with Haemophilus influenzae type b polysaccharude-tetanus protein conjugate vaccine in the Gambia. JAMA 1996;275:11818 .

9. Englund J.Á., Glesen W.P., Thompson C. et al. Haemophilus influenzae type b-specific antibody in infants after maternal immunization. Pediatr Infect Dis J 1997;16:1122-30.

10. Zaleznik D.F., Rench M.A., Hillier S., et al. Invasive disease due to group B Streptococcus in pregnant women and neonates from diverse population groups. Clin Infect Dis 2000;30(2):276-81.

11. Linder N., Ohel G. In utero vaccination. Clin Perinatol 1994;21:663-74.

12. Englund J.Á., Glesen W.P. Maternal Immunization for the prevention of infection in early infancy. Semin Pediatr Infect Dis 1991;2:225-31.

13. Centers for Disease Control. Advisory Commitee on immunization pratices. Prevention and control of influenza. MMWR 1997;46 (RR-9):1-25 (Abstr).

14. Amstey M.S., Insel R., Munoz J., Pichichero M. Fetal-neonatal passive immunization against Haemophilus influenzae, type b. Am J Obstet Gynecol 1985;153:607-11.

15. Santosham M., Reid R., Ambrosino D.M., et al. Prevention of Haemophilus influenzae type $\mathrm{b}$ infections in higth-risk infants treated with bacterial polysaccharide immune globulin. N Engl J Med 1987;317:923-9.

16. Chandra R. Immunocompetence is a sensitive and functional barometer of nutritional status. Acta Pediatr Scand Suppl 1991;374:129-32.

17. FIBGE. Perfil Estatístico de Crianças e Mães Brasileiras. 19741975. Fundação Instituto Brasileiro de Geografia e Estatística Rio de Janeiro, RJ, 1982.

18. Engstrom E.M., Anjos L.A. Défcit estatural nas crianças brasileiras: relação com as condições sócio-ambientais e estado nutricional materno. Caderno Saúde Pública 1999;15(3):559-67.

19. Furlan J.P., Guazzeli C.A.F., Papa A.C.S., et al. A influência do estado nutricional da adolescente grávida sobre o tipo de parto e o peso do recém-nascido. Rev Bras Ginecol Obstet 2003;25(9):625-30.

20. Rosado L.E.F.P.L. Estado nutricional de gestantes adolescentes e sua relação com o peso do recém-nascido em Viçosa MG [tese]. São Paulo: Univ. Federal de São Paulo; 1998.

21. Rosso P. Placental growth, development and function in relation to maternal nutrition. Fed Proc 1980;39(2):250-4.

22. Greenwood B.M. Epidemiology of acute lower respiratory tract infections, especially those due to Haemophilus influenzae type b, in The Gambia, West Africa. J Infect Dis 1992;165:S26-8.

23. Janeway C.A. Jr., Travers P. The humoral immune response. In: Immunobiology. The immune system in health disease. $2^{\text {nd }}$ Current Biology, London 1996;8:1-8:52. 
24. Moraes-Pinto M.I., Hart C.A. Transplacental antibody transfer and neonatal immunity. Br J Hosp Med 1997;58(7):317-9

25. Moraes-Pinto M.I., Verhoeff F., Chimsuku L., et al. Placental antibody transfer: influence of maternal HIV infection and placental malaria. Arch Dis Child Fetal Neonatal 1998;79:F202-F5.

26. Moraes-Pinto M.I., Farhat C.K., Carbonare S.B., et al. Maternally acquired immunity in newborns from women infected by the human immunodeficiency virus. Acta Paediatr 1993;82(12): 1034-8.

27. Moraes-Pinto M.I., Almeida A.C.M., Kenj G., et al. Placental transfer and maternally acquired neonatal IgG immunity in HIV infection. J Infect Dis 1996;173(5):1077-84.

28. Brair M.-E., Brabin B.J., Milligan P., et al. Reduced transfer of tetanus antibodies with placental malaria. Lancet 1994;343(8891):208-9.

29. Nagao AT, Costa-Carvalho BT, Arslanian C, Sole D, Naspitz C, Carneiro-Sampaio MM. Placent transfer of IgG against Haemophilus influenzae type b capsular polysaccharide in Brazilian term and preterm newborns. Journal of Tropical Pediatrics 1999 jun;45(3):171-3.

30. Rosso P.A. New Chart to Monitor Weigth Gain during Pregnancy. Am J Clin Nutr 1975;41:644.

31. Kayhty H., Karanko V., Peltola H., Makela P.H. The protective level of serum antibodies to the capsular polysaccharide of Haemophilus influenzae type b. J Infect Dis 1983;147:1100.

32. Long K.Z., Nanthakumar N. Energetic and nutritional regulation of the adaptive immune response and trade-offs in ecological immunology. Am J Hum Biol 2004;16(5):499-507.
33. Bhaskaram P. Immunobiology of mild micronutrient deficiencies. Br J Nutr 2001;85 Suppl 2:S75-80.

34. Bhaskaram P. Micronutrient malnutrition, infection, and immunity: an overview. Nutr Rev 2002;60(5 Pt 2): $\mathrm{S} 40-5$.

35. Serrano C.V., Puffer R.R. Dados del peso ao nascer y la mortalidade en hospitals uilizados como indicadores de los problemas de la salud en la infancia. Bol Ofic Sanit Panamer 1975;78:93-119.

36. Englund J.A., Glezen W.P. Maternal immunization with Haemophilus influenzae type $\mathrm{b}$ vaccines in different populations. Vaccine 2003;21(24):3455-9.

37. Nahm M.H., Glensen P., Englund J. The influence of maternal immunization on light chain response to Haemophilus influenzae type b vaccine. Vaccine 2003;21:3393-7.

38. Michaux J.C., Heremans J.F., Hitzig W.H. Immunoglobulin levels in cord blood serum of negroes and caucasuans. Trop Georg Med 1996; $18: 10-4$

39. Longo L.D. Disorders of placental transfer. In: Assau MS. Phatophysiology of gestation. New York and London, Academic Press 1972:1-76.

40. Barbosa A.D.M., Kolpeman B.I., Amâncio O.M.S., Patrício F.R. Alterações de peso tecidual e histológicas placentárias, hepáticas e pulmonares em ratas gestantes submetidas a desnutrição e estresse crônico de nicotina e alterações de peso tecidual e histológicas hepáticas e pulmonares e de fosfolipídios pulmonar em seus recém-nascidos. São Paulo 1992; sn:75p.ilus, tab. 